и оценках, а так же сужении, спецификации области научных исследований. Так же он позволяет выделить существование трех различных подходов в рассмотрении проблемы самоотношения:

- самоотношения как аффективного компонента в концепте самосознания, то есть как единице самосознания;

- устойчивой черты личности ее месте и роли в структуре личности;

- компонента саморегуляции личности.

\title{
Литература
}

1.Емельянов Ю.Н. Стремление к самотождественности как социальная потребность индивида // Проблемы формирования социогенных потребностей. - Тбилиси: Мицниереба, 1981. - С. 97-100.

2.Столин В.В. Самосознание личности / В.В. Столин. - М.: Издательство московского университета, 1983. - 288 с.

3.Пантилеев С.Р. Самоотношение как эмоционально-оценочная система. М.: МГУ, 1991. $-110 \mathrm{c}$.

4. Гавриленко А.А. Образ физического Я как структурная составляющая Яконцепции: автореф. дис. ... канд. псих. наук / А.А. Гавриленко; ИСУП Государственного университета управления. - М., 2009. - 18 с.

5. Кисляковская В.В., Клецкова И.М. Методологическое обоснование культурно-исторического подхода к пониманию телесности [Электронный ресурс] / В.В. Кисляковская, И.М. Клецкова // СибАк, 2009. - Режим доступа: http://sibac.info/index.php. - 10.03.2014.

6.Столин В.В., Пантилеев С.Р. Опросник самоотношения / В.В. Столин, С.P. Пантилеев // Практикум по психодиагностике: Психодиагностические материалы. - М., 1988. - 123-130 с.

\section{ФОРМЫ ПРОЯВЛЕНИЯ СТРАХА СМЕРТИ}

Кравченко Л.В.

В современном мире, учитывая ритм жизни, человек постоянно сталкивается со сложными, стрессовыми ситуациями, испытывая при этом тревогу. Первоисточником тревожного состояния, по мнению многих исследователей, является страх смерти. Тема смерти и вызывающих ее осознание эмоций была и остается актуальной во все времена истории человечества. Интерес к этой категории возник в умах еще древних философов Сократа, Платона, Эпикура.

Наиболее разработанной, с психологической точки зрения, проблема отношения к смерти предстает в контексте современной теории страха и тревоги. Многие авторы сходятся во мнении, что в основе любого страха лежит страх смерти (физической, психологической, социальной). Различные научные психологические школы (психоанализ, экзистенцианализм, гештальттерапия и другие) занимались этой проблематикой.

Страх смерти дает нам возможность осознания всей ценности нашей жизни, заставляя при этом познать все ее грани, увидеть различные оттенки, 
является стимулом и побудителем. При этом существуют психологические защиты, которые негативно воздействуют на человека. К ним можно отнести отрицание и игнорирование существования страха смерти как чего-то неестественного в жизни индивида. Такая реакция может привести к необдуманным действиям, непоправимым последствиям. Но ощущение страха смерти может вызвать и другую реакцию. В некоторых обстоятельствах, при высоком психологическом напряжении, а также в силу индивидуальных характерологических особенностей, человек не выдерживает эмоционального воздействия страха смерти, что впоследствии является причиной возникновения различных форм психической патологии, прежде всего тревожных расстройств.

Таким образом, в результате теоретического анализа, нами были выделены три формы проявления страха смерти в жизни человека.

1. Активная - избегание.

При данной форме проявления страха смерти человек проявляет активность в максимальном избегании источников смертельной угрозы в своем субъективном восприятии. В результате это поведение приводит к повышению тревожности, появлению фобий невротического характера. Источники возникновения страха смерти могут быть различны. Это могут быть события, определенные люди или ситуации, которые воспринимаются как опасность. Для одних стимулом для возникновения страха является замкнутое пространство, для других одиночество или большое скопление людей. Иногда человек перемещает свои страхи на безобидные с виду объекты, столкновения с которыми он может легко избежать, не встречаться с ними. Истинный источник страха - страх смерти, скрывающийся под различными страхами, за комплексами защитных механизмов, реакций, уходит глубоко в бессознательное. При этом интенсивность переживания страха может доходить до фобических реакций. При таких проявлениях страха смерти человек замыкается на своих переживаниях.

2. Активная - конфронтация.

В данном случае человек активно отрицает наличие у себя самого страха смерти или вступает с ним в конфронтацию. При такой форме проявления страха смерти можно пронаблюдать несколько вариантов поведения человека:

- стремится к участию в экстремальных видах деятельности (экстремальные виды спорта, опасная профессиональная деятельность и так далее), что можно интерпретировать как отрицание страха смерти или как активную форму борьбы со страхом. При этом человек постоянно «ходит по лезвию ножа», балансируя на грани жизни и смерти. При такой форме поведения может сформироваться так называемая адреналиновая зависимость, которая усугубит ситуацию.

- демонстрирует суицидальные наклонности, а также склонен к различным видам зависимостей (алкогольная, наркотическая и др.). При суицидальном поведении и различного рода зависимостях («латентный суицид») срабатывает немного другой механизм. Осознание страха смерти переходит в активную 
форму и единственный способ избавиться от него (по мнению человека) покончить с жизнью.

3. Пассивная - латентная.

В данном случае у человека имеется страх смерти, но он имеет адаптивную форму проявления, это не доставляет каких-либо проблем в жизнедеятельности человека. Каждый человек испытывает страх смерти в той или иной мере, в данном случае это выступает как функционально необходимый фактор для благополучного биологического и социального существования человека. Положительное воздействие страха заключается в функции предупреждения об опасности, которое вытекает из сложившихся обстоятельств.

Таким образом, наиболее адаптивной является «Пассивная - латентная» форма проявления страха смерти. Дальнейшие исследования могут быть направлены на конкретизацию и уточнение данной классификации.

\section{РОЛЬ ДИАЛОГА В СТРУКТУРИРОВАНИИ ВРЕМЕНИ Кравцова Я.В., Дубовицкая Т.Д.}

Многообразие жизненных сфер, в которые вовлечен современный человек, их определенная привлекательность и доступность, а также ориентация человека на получение удовольствия «здесь и сейчас», на то чтобы чувствовать удовлетворенность собой и происходящим, приводят к тому, что одной из серьезных психологических проблем человека становится распределение времени и определение жизненных приоритетов. Одними из направлений решения данных проблем являются разработанные и широко востребованные тренинги тайм-менеджмента и лайф-менеджмента. И если первое (таймменеджмент) представляет собой учет и оперативное планирование времени, то второе (лайф-менеджмент) - это фактически упорядочивание времени жизни в целом. При этом всесторонне декларируется тезис, что основной секрет личной эффективности заключается в правильном распределении времени. Также можно утверждать, что ориентиром уровня достижений и самоэффективности является сравнение себя с другими, с которыми человек общается, взаимодействует и вступает в диалог. И именно качество диалога субъектов общения во многом определяет продуктивность данного взаимодействия, что может служить главным ориентиром в последующем распределении и наполнении человеком конкретного содержания своего времени.

Действительно, на что тратит свое жизненное время человек и какое значение в нем отводится такой форме коммуникации как диалог? Одной из значимых задач тайм-менеджмента является определение и расстановка приоритетов: что главное на данный момент, что второстепенное и т.п. Расстановка приоритетов позволяет эффективно управлять списком намеченных дел, присваивая каждому делу свой уровень важности. Следует отметить, что, решая эту задачу, человек не получает никаких ориентиров для выявления приоритетов. Он делает это опираясь на свои внутренние ощущения, прежний опыт, а также рекомендации других людей, которые могут быть очень противоречивы. В этой связи возникает практический запрос на выявление и 